Ankara University Journal of Faculty of Educational Sciences

Year: 2021, Volume: 54, Issue: 1, 141-173

DOI: 10.30964/auebfd.742803, E-ISSN: 2458-8342, P-ISSN: 1301-3718

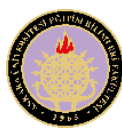

\title{
Difficulties in Learning English by EFL Students in \\ Turkey $^{1}$
}

\begin{tabular}{lccc}
\hline ARTICLE TYPE & Received Date & Accepted Date & Published Date \\
Research Article & 05.26 .2020 & 11.12 .2020 & 02.12 .2021 \\
\hline
\end{tabular}

\section{Demet Özmat}

Çankaya University

\author{
Nuray Senemoğlu \\ Hacettepe University
}

\begin{abstract}
The purpose of this study is to identify the English language learning difficulties. 2317 secondary and high school students from the state schools of the Ministry of Education in Ankara were included in this study. The data was gathered through the Foreign Language Learning Difficulties Scale (LLDS) developed (2017) by researchers and semi structured interviews. Mixed-method research was used which utilizes both quantitative and qualitative methods. Quantitative data was analyzed through SPSS, a statistical program for social sciences research, and the qualitative data was analyzed through MaxQda 12, software for qualitative and mixed methods research with 70 students in total. It was found that $7^{\text {th }}$ and $11^{\text {th }}$ grade students had high levels of difficulties in learning English. When the difficulties between the two grades were compared, it was found that $7^{\text {th }}$ grade students had lower levels of language learning difficulties than $11^{\text {th }}$ grade students. According to the semi structured interview results, the most common difficulties experienced by students were insufficient communicative practice in textbooks, insufficient use of visual and audio instruments in the classrooms, insufficient practices of listening and speaking abilities, lack of language learning teaching strategies, low self-confidence, crowded classrooms and disciplinary problems.
\end{abstract}

Keywords: Foreign language learning, curriculum and instruction, mixed methods research, foreign language learning difficulties scale, scale development study.

The Ethical Committee Approval: Ethical consent was obtained from Hacettepe University Ethical Committee, No: 35853172/ 433-1058, Date: 08.04.2016 and from the Provincial Directorate of National Education-Ankara, No: 14588481-605.99-E.5149315, Date: 09.05.2016.

\footnotetext{
${ }^{1}$ This article is a part of a doctoral dissertation presented and accepted in 2017, December under supervision of Prof. Dr. Nuray Senemoğlu by the department of Curriculum and Instruction at Hacettepe University. ${ }^{2}$ Corresponding Author: Ph. D., Department of Foreign Languages, e-mail: demetgulsoy@ cankaya.edu.tr, https://orcid.org/0000-0002-8936-020X

${ }^{3}$ Prof. Dr., Faculty of Educational Sciences, Curriculum and Instruction, e-mail: n.senem @ hacettepe.edu.tr, https://orcid.org/0000-0001-9657-0339
} 
Communication ability in a foreign language is necessary to keep pace with science and technology in today's global society. Students should have command of one or more foreign languages in order to be successful in both higher education and professional life after school (Council of Higher Education, 2007). Students are expected to use foreign languages effectively and efficiently for academic internationalization in a communicative way. In line with this, studies about teaching and learning English as a foreign language in Turkey focused on how to provide better instruction. According to researches and curriculum evaluation studies, teaching and learning a foreign language in Turkey today have various problems (A Babanoğlu, 2018; Demir-Ayaz, Özkardaş, and Özturan, 2019; Demirpolat, 2015; Erdem, 2016; Gürel and Demirhan-İşcan, 2020; Öztürk and Aydın, 2019; Soğuksu, 2013; The Economic Policy Research Foundation of Turkey (TEPAV) and British Council, 2013).

Some studies in Turkey tried to determine the problems in English teaching and learning by evaluating the English language teaching curricula according to the opinions of teachers, directors or inspectors (Aksoy, 2020; Cihan and Gürlen, 2013; Demirtaş and Erdem, 2015; Dinçer and Koç, 2020; Gürel and Demirhan-İscan, 2020; Er, 2006). The results of these studies show that the most common problems can be summarized as inadequate time allotment for English course hours, difficulty in measurement of the listening and speaking skills, scarcity of suitable language teaching materials, coursebooks were not suitable for the needs of students, the objectives in the English curricula were above the level of students, course books were inadequate, classrooms were too crowded. In addition to these, Ağçam and Babanoğlu (2018) compared the year 2017 English curricula of primary school and secondary school. They found that primary school English course objectives focused on students' lower-rather than higher-order cognitive skills, and the higher order skills were seemingly neglected.

In addition to these curriculum evaluation studies, Demir-Ayaz et al., (2019) presented the problems of English language teaching in high schools in Turkey and suggested ways to overcome them. According to the findings of the study, most teachers were dissatisfied with the English coursebooks, limited teaching hours, very crowded classrooms and students having low level of motivation. According to the studies (Akdoğan, 2010; Akkuş, 2009; Sevinç, 2006) on the common problems of English language teaching in Turkey, the results can be summarized as, high usage of grammar-translation method in language teaching instead of communicative method, class sizes, student's lack of efficiency in their mother language, lack of effective teaching materials, limited use of teaching aids and technology by the teachers; lack of confidence of students.

Studies on English language proficiency levels in Turkey are underwhelming. The English language proficiency levels of Turkish students are below expectations based on average TOEFL scores in the country, which are rather low. In 2011, the average TOEFL score among Turkish students was 77 , which resulted in a ranking of 
93 out of 161 countries using the $193 \mathrm{H}$-index score, (TEPAV and British Council, 2013). An examination of the 2014 English Proficiency Index results showed that Turkey ranked 47th out of 63 countries and last among European countries (Education First English Proficiency Index, 2015). Additionally, the English language portions of the Undergraduate Placement Exam results are rather low. For example, the average score in 2017 was 22.73 . The averages of the correct responses are one/fourth of the number of questions (Student Selection and Placement Center, 2017). Regarding these international and national exam results of Turkey and previous research results summarized above, it can be concluded that there are problems in teaching and learning English as a foreign language in our country.

The aims of this study are to determine the perceived difficulties in English language learning as a foreign language according to secondary and high school students; and to identify possible strategies to meet the perceived difficulties associated with English language learning. It is assumed that the results of this study will contribute to existing literature regarding the improvisation of teaching and learning issues associated with English language learning for teachers, students, English language curriculum development specialists, and practitioners. In addition to these, the results of this study will also contribute to the English language curriculum developments of higher education policies and guide them to the sources of problems in order to find solutions for them.

Compare to previous studies, it can be said that this study indicates a difference in terms of the number of participants which is 2317 from the capital city of Turkey. Additionally, this study can be distinguished from previous studies focusing on a similar topic as it is tried to determine and analyse the higher number of students' perceptions about language learning challenges and it would be helpful to provide a comprehensive look at the problem. As this study provides students' perceptions, it could be regarded as a supportive and complemental one besides the studies on teachers' perceptions. It is regarded also valuable in terms of developing an original scale to determine the challenges in the language learning process which could be used for further researches in foreign language teaching and learning.

In this respect, it can also set light to answer the question of how to teach and learn a foreign language better. To that end, this study examined students' perceptions of language learning difficulties specifically associated with learning English as a foreign language, and addressed the following research questions:

1.What is the level of language learning difficulties of $7^{\text {th }}$ and $11^{\text {th }}$ grade students in the language learning process according to LLD Scale?

2.What difficulties associated with teaching and learning do students $\left(7^{\text {th }}\right.$ and $11^{\text {th }}$ grade) experience in the process of English language learning according to interviews?

3.Is there a significant difference between perceived difficulties associated with English language learning between student groups ( $7^{\text {th }}$ and $11^{\text {th }}$ grade $)$ ? 


\begin{abstract}
Method
The study aimed to identify the perceived difficulties in English language learning as a foreign language according to the views of secondary and high school students. In order to determine these difficulties by mixed method, data was derived through both quantitative and qualitative research methods. As a quantitative method, descriptive statistics (the level of language learning difficulties of $7^{\text {th }}$ and $11^{\text {th }}$ grade students in the language learning process, mean, percentage and frequency values) of the Language Learning Difficulties Scale (LLDS) were calculated by using the SPSS program. In order to determine whether there is a significant difference between perceived difficulties associated with English language learning between student compared the responses of students in different grades. As a qualitative method, to identify the opinions of students content analysis relied on the MaxQda program by determining codes and themes. Ethical consent was obtained from Hacettepe University Ethical Committee (No: 35853172/ 433-1058) and from the Provincial Directorate of National Education-Ankara (No: 14588481-605.99-E.5149315).
\end{abstract}

\title{
Participants
}

The study population is the smaller representative and accessible subgroup of the population (Karasar, 2005). The study population of this research was 716 secondary schools and 79 Anatolian high schools in total in Ankara. Subgroups were determined according to the success levels of schools and students from these subgroups were chosen. The study group of this research included 994 seventh grade students (440 female and 500 male) from secondary state schools and 1,373 eleventh grade (616 female and 757 male) students from Anatolian high schools. 2,317 students in total were included according to the accessibility and regarding voluntary basis.

In order to determine the schools for the study group, stratified purposive sampling technique was used. The aim of this sampling is to divide the population into homogeneous subgroups and then select subjects from each subgroup, rather than the population as a whole. It is used to provide that an adequate number of subjects are selected from different subgroups so the sample will be more representative of the population than if taken from the population as a whole (McMillan, 2012; Patton, 1990).

To determine the secondary schools' success levels for the study, the National Placement Test results (2014) were used. There were 132 schools (twenty percent) that were below the one standard deviations of the mean (low group), 434 schools (sixty percent) were 2 standard deviation between the upper and below levels of the mean (medium level group) and 150 schools (twenty percent) were above the one standard deviation of the mean level (high level group). Then, 2 schools among higher level groups, 3 schools among medium level groups and 2 schools among lower level groups were determined for the study regarding voluntary basis and collaboration.

In order to determine the high schools according to their success levels, 20142015 year transition from primary to secondary education test (TEOG) scores were used. 16 high schools (twenty percent) were below the one standard deviation of the 
mean (low group), 48 high schools (sixty percent) were 2 standard deviations between the upper and below levels of the mean (medium level group) and 15 high schools (twenty percent) were above the one standard deviation of the mean level (high level group). Among these high schools, 3 for higher level groups, 5 schools among medium level groups and 3 schools among lower level groups were determined for the study regarding voluntary basis and collaboration.

Seventh and eleventh grade students were chosen due to their ability to share their perceptions of language learning difficulties experienced in primary and secondary school language learning instruction. Students in eighth grade were excluded as they were engaged with the high school entrance exams. Eleventh grade students were chosen because they were regarded as decisive and consistent enough in sharing their ninth and tenth grade language teaching and learning experiences. In order to make their opinions more decisive about previous grades and increase their experiences in language learning, the upper grades were chosen. Similarly, twelfth grade students were excluded because they were engaged with the university entrance exams. The excluded groups had not been accessible in providing the sufficient number of students.

40 secondary school students in the seventh grade (twenty-eight females, twelve males) and 30 high school students in the $11^{\text {th }}$ grade (nineteen females, eleven males) participated in qualitative data collection through face-to-face interviews. The qualitative data of the study consists of 70 students in total. In order to choose these participants among the target study population random sampling method was used

\section{Data Collection Tools}

The Language Learning Difficulties Scale (LLDS) and semi structured interview forms were used to collect the data of this study. The LLDS was implemented in the chosen secondary and high schools during the 2016-2017 academic year with 2317 students in total. Then, 70 students participated in qualitative data collection through face-to-face interviews in the same academic year. The interviews were tape-recorded after the permission of the participants and then transcribed.

The Language Learning Difficulties Scale (LLDS). The LLDS was developed in order to collect data for this study by the researchers through an extensive literature review of foreign language learning difficulties. (1) Following the review, twenty high school and fifteen secondary school students participated in an interview to determine the difficulties that Turkish students have in learning English. (2) Seven English teachers were interviewed in order to determine teacher views on language learning difficulties. (3) High school and secondary school English lessons were observed for 4 hours to get more detailed data. (4) Following data collection to inform the creation of the LLDS, a table of specification was formed to synthesize the data. (5) Emergent data revealed four categories of difficulties related to English language learning, namely: learning materials, the teaching and learning process, individual student difficulties, and the learning environment. (6) Finally, ten academicians were consulted to review the scale and provide feedback. The instrument included 55 items 
that were tested in a pilot study with 437 students. The pilot study group was chosen using random sampling method.

Exploratory factor analysis was applied to the data from both high school and secondary school students. Before the analysis, the Kaiser-Meyer-Olkin Test was applied and calculated as .83. Bartlett test was calculated as significant ( $<<.01)$. Factor loadings of secondary school students' pilot scale range from .13 to .63. Kaiser- MeyerOlkin Test was calculated as .86 and Bartlett test $(\mathrm{p}<.01)$ was calculated as significant from the data of high schools' pilot scale. Factor loadings of high school students' pilot scale range from .19 to .65 . Thus, fifteen items below . 30 were extracted from the scale.

The 40-item single factor design of the 5 likert scale was then tested in a subsequent study during the 2016-2017 academic year. A second exploratory factor analysis was done for the final form of the LLDS with 2317 secondary and high school students participating. The factor loadings of secondary students' final scale ranged from .37 to .64 with a variance score of 33.46 and a reliability value of .93 . The factor loadings of the high school students' final scale ranged from .35 to .67 with a variance score of 31.33 and a reliability value of .92 . According to the Reckase (1979), a percentage of $20 \%$ or more of the total variance explained by the first principle component is necessary for the data in order to be viewed as unidimensional.

The highest score of the scale is 200 as a 5 likert scale from 1 to 5 . The levels of the scale were calculated using $5-1=4,5 / 4=0.75$ formula which means $1.00-1.80$ is regarded as very low level difficulty; 1.80-2.60 is regarded as low level difficulty; 2.60-3.40 is regarded as medium level difficulty; $3.40-4.20$ is regarded as high level difficulty; and 4.20-5.00 is regarded as very high level difficulty. In other words, from 1 to 5 the difficulty levels of students increased.

Semi-structured Interview Form. The interview questions were formed to parallel the items in the LLDS. The questions in the semi-constructed form were created to focus on four categories that were expected to be explained deeply. Four English teachers and an assessment and evaluation field expert were consulted to ensure content validity. Additionally, seven students were interviewed to determine question clarity, which resulted in a final version of the interview form (Appx-C).

\section{Data Analysis}

In order to determine the level of language learning difficulties of $7^{\text {th }}$ and $11^{\text {th }}$ grade students in the language learning process, mean, percentage and frequency values of LLDS were calculated by using the SPSS program. In order to determine whether there is a significant difference between perceived difficulties associated with English language learning between student groups, the t-test compared the responses of students in different grades. To identify the opinions of students content analysis relied on the MaxQda program by determining codes and themes. Miles and Huberman's (1994) intercoder reliability formula was used to measure consistency among coders and resulted in an intercoder reliability measure of .81. Frequency and percentage values of codes were also determined. 


\section{Results}

In order to determine the language learning difficulties of $7^{\text {th }}$ and $11^{\text {th }}$ grade students, mean (Table 1) and frequency and percentage values (App. A-B) of the LLD Scale were examined. Although the scale is unidimensional, the results were presented by categorizing as in order to make the results more understandable and clear.

Table 1

LLD Scale Mean Values of $7^{\text {th }}$ and $11^{\text {th }}$ Grade Students

\begin{tabular}{|c|c|c|}
\hline Factors That Make Learning English Language Difficult & $7^{\text {th }}$ Grade & $11^{\text {th }}$ Grade \\
\hline \multicolumn{3}{|l|}{ Difficulties related to learning materials } \\
\hline $\begin{array}{l}\text { 1. The reading texts in our English course books are not } \\
\text { interesting. }\end{array}$ & 3.42 & 4.20 \\
\hline $\begin{array}{l}\text { 2. The reading texts in our English coursebooks do not include } \\
\text { topics about daily life. }\end{array}$ & 3.43 & 4.42 \\
\hline $\begin{array}{l}\text { 3. I do not like reading texts because there are too many unfamiliar } \\
\text { English words. }\end{array}$ & 3.79 & 4.06 \\
\hline $\begin{array}{l}\text { 14. I am bored when we do listening practice because the topics } \\
\text { are not interesting. }\end{array}$ & 3.75 & 4.80 \\
\hline $\begin{array}{l}\text { 15. Speaking English is not important to me because there is no } \\
\text { speaking component in our exams. }\end{array}$ & 4.03 & 4.94 \\
\hline \multicolumn{3}{|l|}{ Difficulties related to teaching and learning process } \\
\hline $\begin{array}{l}\text { 5. We do not do any reading practices on how to understand a text } \\
\text { with the guidance of a teacher. }\end{array}$ & 3.71 & 4.37 \\
\hline $\begin{array}{l}\text { 7. I have difficulty in writing a paragraph as we do not practice } \\
\text { often enough in English lessons. }\end{array}$ & 3.37 & 4.82 \\
\hline $\begin{array}{l}\text { 8. We do not practice writing on how to write a paragraph with the } \\
\text { guidance of a teacher in English lessons. }\end{array}$ & 3.57 & 4.83 \\
\hline $\begin{array}{l}\text { 9. It is not clearly explained how to connect the topic and } \\
\text { supporting sentences in a writing process. }\end{array}$ & 3.81 & 3.03 \\
\hline $\begin{array}{l}\text { 12. I have difficulty in listening comprehension as we do not } \\
\text { practice listening exercises in lessons. }\end{array}$ & 4.05 & 4.08 \\
\hline $\begin{array}{l}\text { 13. There is no focus on listening strategy or how to understand a } \\
\text { recording in English lessons. }\end{array}$ & 4.56 & 3.98 \\
\hline $\begin{array}{l}\text { 17. I do not make an effort to speak English because we are } \\
\text { allowed to speak Turkish in English lessons. }\end{array}$ & 3.38 & 4.21 \\
\hline $\begin{array}{l}\text { 19. We are not given any methods to improve our spoken fluency } \\
\text { in English. }\end{array}$ & 3.52 & 4.20 \\
\hline 22. Our English lessons do not include pronunciation classes. & 3.64 & 4.74 \\
\hline $\begin{array}{l}\text { 26. We are not given any strategies to help us remember new } \\
\text { English vocabulary. }\end{array}$ & 3.59 & 4.05 \\
\hline $\begin{array}{l}\text { 27. I have difficulty in making a sentence as we only practice } \\
\text { grammar tests while learning English grammar. }\end{array}$ & 4.23 & 4.66 \\
\hline $\begin{array}{l}\text { 34. I put an emphasis on studying other lessons as we are allowed } \\
\text { to study them in English lessons instead of studying English. }\end{array}$ & 2.97 & 3.40 \\
\hline
\end{tabular}


Tablo 1 (devam)

\begin{tabular}{|c|c|c|}
\hline Factors That Make Learning English Language Difficult & $7^{\text {th }}$ Grade & تrade \\
\hline & $\bar{X}$ & $\bar{X}$ \\
\hline $\begin{array}{ll} & \text { Difficulties caused } \\
\end{array}$ & y students & elves \\
\hline $\begin{array}{l}\text { 4. I do not like reading as I cannot understand a text without teacher } \\
\text { guidance. }\end{array}$ & 3.74 & 3.98 \\
\hline $\begin{array}{l}\text { 10. I cannot make a sentence while writing a paragraph as I struggle } \\
\text { with even basic grammatical topics. }\end{array}$ & 3.63 & 3.96 \\
\hline $\begin{array}{l}\text { 11. I have difficulty in writing a paragraph as I lack confidence } \\
\text { without teacher guidance. }\end{array}$ & 3.92 & 4.42 \\
\hline $\begin{array}{l}\text { 18. I do not want to speak English because I always have to translate } \\
\text { from Turkish first, so it takes me a long time to make sentence. }\end{array}$ & 4.92 & 4.35 \\
\hline $\begin{array}{l}\text { 20. I do not believe I can speak English because I want to speak } \\
\text { fluently without making a mistake. }\end{array}$ & 3.85 & 4.14 \\
\hline 21. I do not feel confident in speaking English. & 3.62 & 4.26 \\
\hline $\begin{array}{l}\text { 24. I have difficulty in speaking English as I don't know enough } \\
\text { vocabulary. }\end{array}$ & 3.78 & 4.75 \\
\hline 25. I do not know how to learn new English words. & 3.61 & 3.40 \\
\hline 28. I am not interested in learning English. & 3.76 & 3.92 \\
\hline 29. I do not allocate any time to learn English out of the classroom. & 3.65 & 4.90 \\
\hline $\begin{array}{l}\text { 30. I always fall behind in English lessons due to gaps in my } \\
\text { knowledge from previous grades. }\end{array}$ & 3.47 & 4.84 \\
\hline $\begin{array}{l}\text { 31. I do not take English seriously as I think other lessons are more } \\
\text { important. }\end{array}$ & 3.55 & 4.62 \\
\hline $\begin{array}{l}32 \text { I cannot achieve a high level of English proficiency because I } \\
\text { only study just before the exams in order to pass. }\end{array}$ & 3.37 & 4.38 \\
\hline $\begin{array}{l}\text { 33. I prioritize other lessons as I believe I can learn English later on } \\
\text { at university preparatory schools. }\end{array}$ & 3.05 & 4.45 \\
\hline 35. I dislike English lessons because I don’t like my English teacher. & 3.39 & 3.40 \\
\hline $\begin{array}{l}\text { 40. I lack confidence in learning English because I have always g } \\
\text { low grades in the past. }\end{array}$ & 3.10 & 4.97 \\
\hline
\end{tabular}

low grades in the past.

Difficulties Related to the Learning environment

6. My reading comprehension cannot be evaluated because our class $\quad 3.52 \quad 2.88$ is overcrowded.

2.88

16. I avoid speaking in English because when I do, my friends making fun of me.

$4.92 \quad 3.40$

23. We cannot practice speaking skills in English because our classroom is overcrowded.

$3.72 \quad 4.28$

36. Strong and hardworking students dominate the lessons so I do not want to participate.

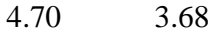

37. I dislike English lessons because our teacher is usually angry and indifferent to us.

38. I do not enjoy learning English because our lessons are generally boring and monotonous.

$3.70 \quad 4.20$

39. I cannot learn English because of discipline issues in our class.

$2.78 \quad 3.76$

Total

$3.59 \quad 4.18$

*1.00-1.80 = very low level difficulty; $1.80-2.60=$ low level difficulty; $2.60-3.40=$ medium level difficulty; $3.40-4.20=$ high level difficulty, 4.20-5.00 =very high level difficulty 
Total mean values of the LLD Scale of both $7^{\text {th }}$ grade $(\bar{X}=3.59)$ and $11^{\text {th }}$ grade ( $\bar{X}=4.18$ ) are high. It is seen that both groups had these difficulties at a high level. As for the difficulties related to learning materials, $70.8 \%$ of secondary school students and $52 \%$ of high school students stated that reading texts in their books were not interesting for them. Secondary school ( $\bar{X}=3.79)$ and high school $(\bar{X}=4.06)$ students stated that they did not like reading as they encountered too many unfamiliar words in reading texts. They both had this difficulty at a high level. In terms of speaking skills difficulties, secondary school students stated that speaking was not important because there is no speaking component in the exams. They had this difficulty at a high level $(\bar{X}=4.03)$ and high school students had this difficulty at very high $(\bar{X}=$ 4.94) level.

As for the difficulties related to the teaching and learning process, both secondary school ( $\bar{X}=3.81)$ and high school ( $\bar{X}=4.03$ ) students stated that they had difficulty in writing a paragraph as the structure of a text and how to connect the topic and supporting sentences in the writing process are not clearly explained in English lessons. Students had this difficulty at a high level. In addition to this, most of the high school students $(73.8 \%)$ stated that they did not practice how to write a paragraph with the guidance of a teacher in English lessons ( $\bar{X}=4.83$ ). 930 students out of 1373 had this difficulty at a very high level. In terms of listening skills, secondary ( $\bar{X}=$ 4.05) and high school ( $\bar{X}=4.08$ ) students stated that they had difficulty in listening comprehension as they did not practice any listening exercises in English lessons. Students had this difficulty at a high level. In terms of speaking skills, secondary school students stated that English lessons did not include the teaching of pronunciation classes. They had this difficulty at a high level $(\bar{X}=3.64)$ and high school students had this difficulty at a very high level $(\bar{X}=4.74)$.

As for the difficulties caused by students themselves, both groups stated that they did not want to speak English because they always had to translate from Turkish first, so it took them a long time to make a sentence (item 18). They had this difficulty at a very high level. In other words, $71.6 \%$ of secondary school $(\bar{X}=4.92)$ and $73.6 \%$ of high school students $(\bar{X}=4.35)$ stated that they had this difficulty. Likewise, both secondary $(\bar{X}=3.85)$ and high school $(\bar{X}=4.14)$ students stated that they could not speak English as they wanted to speak it fluently and without making a mistake. In addition to these, secondary ( $\bar{X}=3.65)$ and high school $(\bar{X}=4.90)$ students stated that they did not all allocate any time for studying English out of the classroom. The secondary school students stated that they lacked confidence in learning English because of low grades in the past (item 40$)$ difficulty at a medium level $(\bar{X}=3.10)$. On the other side, high school students had this difficulty at a very high level $(\bar{X}=$ 4.97). 
As for the difficulties with the learning environment, secondary ( $\bar{X}=3.48$ ) and high school students $(\bar{X}=3.76)$ stated that their reading comprehension skills cannot be evaluated because of overcrowded classrooms. Students had this difficulty at a high level. In addition to this, secondary school students stated that they could not learn English because of disciplinary problems difficulty. They had this difficulty at a medium level ( $\bar{X}=2.78$ ). On the other hand, high school students had this difficulty at a high level $(\bar{X}=3.76)$.

\section{Students' Scores on LLD Scale Compared to Their Grades}

In order to determine the difference between the $7^{\text {th }}$ and $11^{\text {th }}$ grade student's opinions on LLD scale independent sample t-test was used. Before the analysis, Levene's test was applied and equal variances were assumed. The results of the t-test were presented in Table 2.

Table 2

T-test Results on Student Scores According to Their Grades

\begin{tabular}{lrrrrrr}
\hline Groups & $\mathbf{n}$ & $\bar{X}$ & $\mathbf{S}$ & $\mathbf{s d}$ & $\mathbf{t}$ & $\mathbf{p}$ \\
\hline $11^{\text {th }}$ Grade & 1373 & 167.60 & 25.30 & 2317 & 19.216 & $<.000$ \\
$7^{\text {th }}$ Grade & 946 & 143.31 & 27.50 & & & \\
\hline
\end{tabular}

Table 2 shows that there is a significant difference between the arithmetic mean ( $\bar{X}=143.31)$ of the $7^{\text {th }}$ grade and arithmetic mean of the $11^{\text {th }}(\bar{X}=167.60)$ grade students on the LLD scale $(\mathrm{t}(2317)=19.216, \mathrm{p}<.05)$. In other words, the difficulty levels of $11^{\text {th }}$ grade students are higher than $7^{\text {th }}$ grade students.

\section{Student Opinions About Language Learning Difficulties}

Data was collected through the semi structured interview forms in order to answer the research questions. All participants allowed the voice recording of the interviews and after recordings were transcribed, the data was analyzed through the content analysis method and MaxQda 12 program. Afterwards, the themes and codes were articulated. While coding, the concepts were extracted from the data of the research according to the research questions. Then, difficulties related to learning materials, difficulties related to teaching and learning process, difficulties related to students themselves and difficulties related to learning environment themes and their codes were formed in Table 3. 
Table 3

Theme, Codes, Frequency and Percentages of Language Learning Difficulties By Students $7^{\text {th }}$ Grade Students 11 $^{\text {th }}$ Grade Students

Theme: Difficulties Related to Learning Materials Theme

\begin{tabular}{|c|c|c|c|c|c|}
\hline Codes & $f(n=40)$ & $\%$ & Codes & $f(n=40)$ & $\%$ \\
\hline $\begin{array}{l}\text { Non-availability of } \\
\text { audiovisual equipment in } \\
\text { English lessons }\end{array}$ & 20 & 50 & $\begin{array}{l}\text { Lack of supplementary } \\
\text { resources to study English }\end{array}$ & 17 & 56 \\
\hline $\begin{array}{l}\text { Too long and unpleasant } \\
\text { reading texts in English } \\
\text { books }\end{array}$ & 20 & 50 & $\begin{array}{l}\text { Inadequate skills teaching } \\
\text { activities (listening/speaking) } \\
\text { in coursebooks }\end{array}$ & 15 & 50 \\
\hline $\begin{array}{l}\text { Lack of adequate technology } \\
\text { support in English lessons }\end{array}$ & 10 & 25 & $\begin{array}{l}\text { Lack of adequate technology } \\
\text { support in English lessons }\end{array}$ & 13 & 43 \\
\hline $\begin{array}{l}\text { Need for English books in } \\
\text { school's libraries }\end{array}$ & 7 & 17 & $\begin{array}{l}\text { Non-availability of audio } \\
\text { visual equipment in English } \\
\text { lessons }\end{array}$ & 10 & 33 \\
\hline \multicolumn{6}{|c|}{ Theme: Difficulties Related to Teaching and Learning Process Theme } \\
\hline Codes & $\mathbf{f}(n=40)$ & $\%$ & Codes & $\mathbf{f}(\mathbf{n}=\mathbf{4 0})$ & $\%$ \\
\hline $\begin{array}{l}\text { Low variety of activities in } \\
\text { English lessons }\end{array}$ & 25 & 62 & $\begin{array}{l}\text { Inadequate listening activities } \\
\text { in lessons }\end{array}$ & 26 & 86 \\
\hline $\begin{array}{l}\text { Too much grammar-translation } \\
\text { homework }\end{array}$ & 20 & 50 & $\begin{array}{l}\text { No speaking practices in } \\
\text { lessons }\end{array}$ & 21 & 70 \\
\hline $\begin{array}{l}\text { Inadequate listening activities } \\
\text { in lessons }\end{array}$ & 15 & 37 & $\begin{array}{l}\text { Too much grammar- } \\
\text { translation based teaching }\end{array}$ & 17 & 56 \\
\hline $\begin{array}{l}\text { No speaking practices in } \\
\text { lessons }\end{array}$ & 15 & 37 & $\begin{array}{l}\text { Too much use of mother } \\
\text { tongue in English lessons }\end{array}$ & 16 & 53 \\
\hline $\begin{array}{l}\text { Ineffective vocabulary } \\
\text { instruction }\end{array}$ & 9 & 22 & $\begin{array}{l}\text { Need for language learning } \\
\text { strategies }\end{array}$ & 16 & 53 \\
\hline \multicolumn{6}{|c|}{ Theme: Difficulties Related to Students Themselves } \\
\hline Codes & $\mathbf{f}(\mathrm{n}=4)$ & $\%$ & Codes & $\mathbf{f}(\mathrm{n}=40)$ & $\%$ \\
\hline $\begin{array}{l}\text { Not allocating enough time to } \\
\text { study English }\end{array}$ & 25 & 62 & $\begin{array}{l}\text { Not allocating enough time to } \\
\text { study English }\end{array}$ & 25 & 83 \\
\hline $\begin{array}{l}\text { Lack of supplementary materials } \\
\text { outside the school }\end{array}$ & 23 & 57 & $\begin{array}{l}\text { Lack of interest in learning } \\
\text { English }\end{array}$ & 20 & 66 \\
\hline $\begin{array}{l}\text { Not knowing how to study } \\
\text { English }\end{array}$ & 26 & 40 & $\begin{array}{l}\text { Low self-confidence in } \\
\text { English }\end{array}$ & 13 & 43 \\
\hline $\begin{array}{l}\text { Low self-confidence in } \\
\text { English }\end{array}$ & 10 & 25 & $\begin{array}{l}\text { Procrastination of learning } \\
\text { English }\end{array}$ & 10 & 33 \\
\hline \multicolumn{6}{|c|}{ Theme: Difficulties Related to Learning Environment Theme } \\
\hline Codes & $f(n=4)$ & $\%$ & Codes & $f(n=40)$ & $\%$ \\
\hline $\begin{array}{l}\text { Discipline problems (bullying in } \\
\text { English lessons) }\end{array}$ & 23 & 57 & $\begin{array}{l}\text { Lack of participation in } \\
\text { English lessons }\end{array}$ & 25 & 83 \\
\hline Overcrowded classes & 19 & 48 & Discipline Problems & 16 & 53 \\
\hline Indifferent teachers & 15 & 37 & $\begin{array}{l}\text { Monotonous learning } \\
\text { environments }\end{array}$ & 11 & 36 \\
\hline
\end{tabular}


The results of the interviews indicated four categories of difficulties as learning materials, the teaching and learning process, individual student difficulties, and the learning environment. Learning materials can cause difficulty in English language learning experiences for a number of reasons. Both seventh $(n=20)$ and eleventh $(n=$ 10) grade students stated that they did not use any audiovisual materials in English lessons. Also, seventh $(n=10)$ and eleventh $(n=13)$ grade students stated that they needed technology integration into English lessons. Twenty secondary grade students out of 40 indicated that the textbooks in their courses did not appeal to them because of length (too long) and uninteresting content. Seven (17\%) of them indicated that there are no English sources in their library which was a hindrance to them studying outside of class. Fifty percent of eleventh grade students stated that their course books did not promote communication skills activities such as speaking or listening. They thought that the books were inefficient to meet their needs and interests, as evidenced in the sample student comment below:

Our course books are very boring. The reading texts have long sentences and the topics and the pictures are not interesting. We enjoy learning with different kinds of exercises, such as games or songs. We like to use smart boards but we do not use them often. We need to speak English; we can watch videos, documentaries, but not books. We are advised to read books but we do not have any books in our library. (S-24)

In terms of the difficulties related to teaching and learning, both $7^{\text {th }}(n=15)$ and $11^{\text {th }}(n=26)$ grade students stated that there were inadequate listening activities in English lessons. Additionally, 15 secondary $\left(7^{\text {th }}\right.$ grade $)$ and 21 high school $\left(11^{\text {th }}\right.$ grade $)$ students stated that they do not practice speaking English during class. Twenty-five out of 40 secondary school students stated that there is a lack of engaging activities such as listening to songs, watching videos, documentaries and so forth (62\%). Twenty of them stated that they have difficulty in doing so much translation homework $(50 \%)$. Sixteen of 30 high school students stated that they generally communicate in their native language so they do not need to speak English (53\%). Likewise, 17 of them stated that the lessons are too focused on grammar at the expense of learning effective communication skills $(56 \%)$. Sixteen of them pointed out that they do not know how to study or learn English. In other words, they do not know how to use language learning strategies when they study or when they are trying to learn in the classroom (53\%). Sample relevant quotation of students is presented below.

We do not practice listening activities in English lessons, and I think I am not good at listening skill since I don't understand anything when I hear an English song on the TV. We should do more listening practices in the lessons so we can also enjoy while learning. Only doing grammar and reading may sometimes be boring, but we have to because of exams. Another problem; it is nearly impossible to speak English in our overcrowded classroom. My turn never comes to me, so we do not speak English. (S-8) 


\section{Some difficulties in English language}

learning are a result of the students, themselves. Twenty-five secondary and 25 high school students said that they allocate little or no time for studying English out of the classroom. In addition to this, 10 secondary and 13 high school students stated that they have low self confidence in learning English. Twenty-three secondary school students out of 40 stated that they do not have any supplementary materials to study at home or somebody to study with. Likewise, 16 of them said that they do not know how to study, or how they can improve their English or where to start studying English. Twenty high school students out of 30 stated that they have difficulty in learning English because they are not interested in learning or studying it. Ten of them said that they always procrastinate studying English or they think that they can learn English when they graduate from high school. Theme-related sample comment shares these concerns about individual difficulties:

There is nobody to study with me at home so I can't ask my questions about English to anybody. Also, I don't know what to study except for doing homework. I sometimes use the internet for English. I generally study English before the exams but we have a lot of other subjects and exams so I don't spend much time for English. Actually, I don't like English because I can't speak it. It is difficult to study English outside the classroom. (S-33)

Both secondary $(n=23)$ and high school $(n=16)$ students said that discipline problems (such as their friends laughing at their pronunciation mistakes) negatively impact the classroom learning environment. Nineteen secondary school students out of 40 stated that overcrowded classrooms cause concentration problems and decrease their motivation to learn English, making English language learning even more difficult. Additionally, ten high school students out of 30 stated that the low level of participation in English language learning classrooms also has a negative effect on the learning environment. Ten students stated that a monotonous learning environment without active students or communicative activities hinders their development in English. These attitudes are exemplified in the sample quotation below.

Our classroom is very crowded, so when I raise my hand to answer a question or speak, my teacher sometimes doesn't realize me. Whenever our friend starts to read an English text or speak, all of the students start to laugh at him/her, so I don't want to speak English in class. Of course, I sometimes tease my friends about their speaking English. (S-8)

\section{Discussion, Conclusion and Suggestions}

This research was designed to identify the factors and the causes that make English language learning difficult for secondary and high school students. According to the results of the LLDS, both seventh and eleventh grade students had high levels of difficulty in learning English (Table 1).

According to the findings about the learning materials, both seventh and eleventh grade students had difficulty with their reading skills because the textbooks were too 
long to understand and students encounter numerous unfamiliar words in them. It was found that seventh grade students had the difficulties of LLD Scale related to learning materials at a high level and eleventh grade students had these difficulties at a very high level. In addition to these, students stated that reading texts in their books were not interesting for them (Table 1). The results of the interviews also supported the findings of the LLD Scale (Table 3). Interview results showed that fifty percent of eleventh grade students stated that their course books did not promote communication skills activities such as speaking or listening. They thought that the books were inefficient to meet their needs and interests and also that fifty percent of seventh grade students stated that reading texts were too long and unpleasant in English books (Table 3). The findings about the learning materials through the LLDS and interviews had results similar to Demir-Ayaz et al. (2019) study on the evaluation of high school English language curriculum. They stated that teachers were also not satisfied with the coursebooks. Güzel-Yüce and Emir (2020) evaluated the $8^{\text {th }}$ grade English language textbooks and stated that they were limited in developing and supporting the culture of thinking skills of students. Çelik (2001) on the evaluation of secondary school student books found that textbooks were not appropriate for the students' needs and they were ineffective in providing information that students need in real life. Similar results on English book evaluation studies showed that learning materials and course books did not promote communication skills, English coursebooks in Turkey were not consistent with the needs and interests of the students they were intended to serve and they were not appropriate to student's levels (Akkuş, 2009; Aslantürk, 2011). O'Neill (1982) stated that there are many ways to design textbooks so that they can be used by a variety of learners with a variety of goals. He provided 4 justifications for the use of course books: First, course textbooks should be suitable for student's needs. Second, course textbooks should provide students with opportunities to review past lessons. Third, course textbooks should provide well-presented material in inexpensive formats. Finally, well-designed course textbooks should provide improvisation, empower student interaction in the class. Thus, it could be concluded that students have difficulty learning English due to poor learning materials.

Interview results also showed that students emphasized the lack of adequate technology support and need for audiovisual equipment in English language learning classrooms (Table 3). These findings are compatible with the results of the study conducted by Aksoy-Tosun and Özaydınlı (2020). They found out that the secondary school English language curriculum was not applicable with technology since materials and sources supported by the MoNE were not appropriate to the blended learning approach and they were of low quality. Also, there was no internet connection in classes and internet line limited the access to other sites that include a variety of content, real life examples that students may need and effective audial and visual materials in developing language skills.

Likewise, Aduwa-Ogiegbaen and Iyamu (2006) and Lamb (2007). AduwaOgiegbaen and Iyamu (2006) found that the failure of secondary school students learning English is related to the less use of modern instructional technologies and 
lack of variety of teaching techniques and materials in English lessons. Özbay and Kayaoğlu (2015) examined the Engliah language teachers' reflections on the use of computerized corpora as a tool for teaching in the classrooms and they found that teachers had not used any tools in their previous teachings. Thus, they advised that the use of computerized corpora needs to be increased by language teachers in order to establish them firmly. Thus, it can be said that the need for the technology support in teaching and learning environments is one of the important factors that hinder students from learning English.

According to the students' perceptions about the learning and teaching process, both $7^{\text {th }}$ and $11^{\text {th }}$ students had difficulty in listening comprehension as they did not practice any listening exercises in English lessons which can be seen as a highly important result. Students had this difficulty at high level (Table 1). In line with this, students also had difficulty in terms of speaking skills and they found listening and speaking activities inadequate. Studens also stated that there was not any speaking component in their exams so they did not give importance to speaking English (Table 1). These results were parallelled the results of the interviews. Both seventh and eleventh grade students stated that there were inadequate listening activities in English lessons. Furthermore, students stated that they did not practice speaking English during the lesson (Table 3). Lamb (2007) found that instruction is mainly teacher centered in many of the classes, written activities are mainly from books, and there are not any communication-related activities. Cihan and Gürlen (2013) found that English teachers ignored the evaluation of speaking and listening skills when evaluating the secondary school English curriculum. In line with this, Yolcu and Dimici (2020) analysed the $5^{\text {th }}$ grade English language curriculum in a broad sense and stated that the deficiencies regarding the speaking and listening skills of the students continued unfortunately. Likewise, Güngör and Fişne (2020) as a result of their results of study, suggested that more space for meaningful, communicative, and natural language use through speaking and listening activities should be given and class hours must be increased in lower levels of English language teaching. Ur (1984) emphasized the importance of engaging students through different, innovative listening activities. Tuan and Mai (2015), emphasized that the biggest challenge for developing speaking skills is not to practice speaking in lessons. Dale and Wolf (1988) determined the difficulties with listening skills as students exposed to boring topics, distracted from the listening texts, being not concentrated and unknown vocabularies in the listening texts.Thus, according to this study's findings, it can be conluded that students consider themselves unsuccessful with speaking and listening skills due to a lack of practice, no assessment or evaluation, and a lack of teaching strategies to enhance skill proficiency.

According to the results, students had high levels of difficulty in writing, listening, and vocabulary learning skills. Even worse, students had no idea how to improve these skill sets. LLDS showed that students did not know how to learn and the ways they need to follow (Table 1). Interviews revealed that students need foreign language learning strategies to enhance their skills (Table 3). Studies on language 
learning strategies (Altan, 2003; Gülsoy, 2011) emphasize the need for language learning and teaching strategies in English teaching and learning. Akkaş-Baysal and Ocak (2020) investigated the need for English language learning strategies for high school students and they found out that especially students who considered themselves unsuccessful in learning English needed language learning strategies and benefited from them.

According to Weinstein and Mayer (1986), good teaching includes teaching students how to learn, remember, and think. Likewise, Rubin (1975) emphasized that effective teaching strategies are important in order to enhance student success in language learning. In short, it can be concluded that students need guidance on how to learn and teaching language learning strategies is an important factor in the teaching and learning process.

Findings in LLDS related to students themselves showed that students hesitate to speak English because of the thought process they experience trying to find Turkish meanings of words, the fear of ridicule from classmates when they make a mistake, and the lack of confidence in speaking English (Table 1). Many studies support these results. For example, Yelgeç and Dağyar (2020) investigated the foreign language anxiety factors of $7^{\text {th }}$ and $8^{\text {th }}$ grade students. They found that students with low selfefficacy beliefs had high anxiety about learning foreign languages.

Taiwanese students (Chen, 2010) and Finnish students (Paaki, 2013) who learn English as a foreign language often fail due to a lack of motivation, lack of confidence in themselves to learn English which results in them feeling too shy to speak, and feelings of inadequacy. MacIntyre, Noels and Clement (1997) found a relationship between learning anxiety and learning a new language. They hold that when the anxiety level increases, students' quality of writing skill and self-efficacy beliefs decrease. Considering these findings, self-confidence is an important element for the development of writing and speaking skills of students. Student reports of low levels of self-confidence may be related to high levels of anxiety and low levels of selfconfidence in the learning process. Additionally, students stated that they give more importance to studying other subjects rather than studying English and they do not allocate extra time for studying English out of the classroom. They claim a lack of interest in learning English, low self-confidence, and not allocating enough time to study English as significant self-imposed difficulties (Table 3). It can be concluded that combining a supportive learning environment with friendly teachers who create awareness among students about the importance of English increases the likelihood of student success in English language learning. These findings related to students themselves generally support the literature. For example, Masgoret and Gardner (2003) emphasized that positive attitudes of students is related to the effort to learn a new language and motivation. They found that when students have positive attitude towards learning a foreign language, they have higher motivation. Sadly, the students in this study suffer from lack of motivation when learning a foreign language. Lack of motivation, reluctance to speak English and not needing to learn a foreign language 
are obstacles that prevent students from learning English. Additionally, students have difficulty in speaking English because of overcrowded classrooms. Likewise, Çelebi and Y1ldiz-Narinalp (2020) investigated the problems encountered in English language teaching in secondary schools and found that the examination system affected English teaching in a negative way, students did not repeat regularly what they learned in the class, the curriculum was not effective, course books were not efficient, there was not enough service training, ministry's solutions were not influential and the classes were overcrowded. Gürel and Demirhan-İşçan (2020) also emphasized the classroom size challenge in language teaching in their study. Stronge (2002) emphasized that a successful teacher can manage the class by providing opportunities for students to learn more effectively and efficiently. One way in which this can be accomplished is through effective classroom management techniques.

A comparison of the difficulties that seventh and grade students reported found that eleventh grade students experienced difficulties at higher levels than the seventh grade students did (Table 2).This finding supports the results of TEPAV and the British Council (2013) regarding their study on English language teaching in Turkey. Their findings suggest that students in higher grades have lower levels of motivation than students in lower grades. Bloom's school learning model emphasized that cognitive behaviors containing prerequisite skills can explain $50 \%$ of the differences in learning. As such, learning beginning units in a gradual sequence (a teaching technique known as scaffolding), prepared students for the subsequent, higher level units. As a result, the differences in learning levels decreased, and students reached higher levels of achievement (Senemoğlu, 1987).

If Turkish students are expected to be good at English language learning, it can be said that it could be better to minimize the difficulties identified by educational scholars and the students. Hopefully, we can improve course materials, use more effective teaching and learning processes in the classroom, motivate students to see the importance of learning English and create safe and supportive classroom climates conducive to effective English language learning. The suggestions according to the results of this study are steps to address these actions. The needs and interests of the students and developing their competency in the English language should be considered in the reorganization of course textbooks. Reading texts in the books should encourage students to read and there should be a balance between the known and unknown English words in the texts. They should be updated in terms of level and content. They should be reorganized inconsistent with the objectives of the curriculum and activities that could help to develop students' speaking and listening skills. Pronunciation teaching should be covered in the curriculum and listening/speaking skills should be tested in the exams. Teachers should participate in training sessions focused on innovative teaching strategies for teaching English as a foreign language. Language learning and teaching strategies should be embedded in the English language curriculum. 
Teachers, school management and counseling services need to raise awareness of language learning and provide counseling and guidance to show the importance of a foreign language in their educational pathway. Students must be motivated to learn English before higher education. The teaching and learning environment should be provided so as to engage students and improve their communication skills. Teachers should be given feedback and opportunity to provide effective communication based environment. Hours allocated for English lessons can be rescheduled, language learning centers can be organized, native speakers may be ensured for schools, the motivation of students should be increased and use of mother tongue need to be decreased in English lessons.

Students need technology integration into English lessons. Technology should be effectively used to cultivate students' interests and motivation, to prepare them for learning, and to improve speaking, listening, reading, and writing skills in accordance with the objectives of the English language curriculum. In-service training on the technology and language teaching for teachers and school management, organizing online classes and online activities may help to overcome this challenge and keep up with the technology age.

English language learning difficulties increased for students in higher grades. We suggest that prerequisite skills and prior knowledge of students should be determined in order to provide benchmark behaviors for each level of instruction. Before starting a new grade, necessary skills should be completed and/or mastered at a certain level of proficiency before moving on to more advanced instruction.

This study was limited to the data gathered from 2,317 secondary and high schools students in Ankara, Turkey and with the data collection tools. For future research, experimental studies focused on the teaching of English as a foreign language can be conducted. These studies could focus on the use and effectiveness of specific teaching and learning strategies in overcoming the difficulties identified in this research. Finally, replication of this study using the LLSD scale on different levels can be implemented and the results can be compared with this study.

\section{The Ethical Committee Approval}

Ethical consent was obtained from Hacettepe University Ethical Committee, No: 35853172/ 433-1058, Date: 08.04.2016 and from the Provincial Directorate of National Education-Ankara, No: 14588481-605.99-E.5149315, Date: 09.05.2016.

\section{References}

Aduwa-Ogiegbaen, S. E., and Iyamu, E. O. S. (2006). Factors affecting quality of English language teaching and learning in secondary schools in Nigeria. College Student Journal, 40(3), 495-504. Retrieved from: http://search.ebscohost.com/login.aspx?direct=true\&db=eric\&AN=EJ765347 site $=$ ehost-live 
Ağçam, R., and Babanoğlu, M.P. (2018). The solo analysis of efl teaching programmes: evidence from Turkey. [İngilizce Öğretim Programlarının SOLO Çözümlemesi: Türkiye Örneği] Turkish Studies Educational Sciences, 13(27), 1-18. doi: 10.7827/TurkishStudies.14255

Akdoğan, S. (2010). Teachers and instructors' views about the problems experienced in foreign language teaching in Turkey and foreign language schools as a proposal [Türkiye'de yabancı dil ögrretiminde karşılaşılan sorunlar ve bir çözüm önerisi olarak yabancı dil okullarına yönelik ögretmen ve öğretim elemanlarının görüşleri] (Unpublished doctoral dissertation). Retrieved from https://openaccess.firat.edu.tr/xmlui/hande/11508/16573

Akkuş, O. (2009). Problems in English learning and teaching in Turkey: Sample of Sivas [Türkiye'de Ingilizce öğrenim ve ögretiminde karşılaşılan sorunlar:Sivas ili örneği] (Unpublished doctoral thesis). Retrieved from https://tez.yok.gov.tr/UlusalTezMerkezi/ (Thesis No. 239712).

Aksoy, E. (2020). Evaluation of the 2017 updated secondary school English curriculum of Turkey by means of theory-practice link. [Türkiye'de 2017'de güncellenen ortaokul İngilizce öğretim programının kuram-uygulama bağ 1 kapsamında değerlendirilmesi]. Turkish Journal of Education, 9(1), 1-21. doi: $10.19128 /$ turje. 575392

Aksoy-Tosun, E., and Özaydınl, F . (2020). Teacher opinions on the applicability of the 2017 secondary education english curriculum based on the blended learning approach. [Harmanlanmış öğrenme yaklaşımına dayalı olarak hazırlanan 2017 ortaöğretim İngilizce dersi programının uygulanabilirliğine ilişkin öğretmen görüşleri]. Journal of Qualitative Research in Education, 8(2), 686-713. Retrieved from https://dergipark.org.tr/tr/pub/enad/issue/54160/732621

Altan, M. Z. (2003). Language learning strategies and foreign language achievement. [Dil öğrenme stratejileri ve yabancı dil başarısı] Education and Science, 28(129), 25-31. Retrieved from: http://egitimvebilim.ted.org.tr/index.php/EB/article/view/5109/1193

Aslantürk, S. (2011). Anadolu liselerinde kullanılan yeni Ingilizce ögretim programı ve ders kitapları hakkında ögretmen görüşlerinin belirlenmesi: Zonguldak ili örneği [Determination of teachers' perceptions about the new English curriculum and course books used in Anatolian high schools: The sample of Zonguldak city] (Unpublished doctoral thesis). Retrieved from https://tez.yok.gov.tr/UlusalTezMerkezi/ (Thesis No. 294699).

Akkaş-Baysal, E., and Ocak, G . (2020). Is the program for foreın language learning strategies a need? [Yabancı dil öğrenme stratejileri öğretim programı bir ihtiyaç mı?.] Nevşehir Hacı Bektaş Veli University Journal of Social Sciences Institue, 10(1) , 306-325. doi: 10.30783/nevsosbilen.619748 
Çelebi, M., and Yıldız-Narinalp, N. (2020). The problems encountered in Englısh language teaching in secondary schools [Ortaokullarda İngilizce Öğretiminde Karşılaşılan Sorunlar]. International Journal of Society Researches, 15(1), 4975-5005. doi: 10.26466/opus.704162

Çelik, Ş. N. (2011). Ortaöğretim İngilizce ders kitabı Breeze 9 hakkında öğrenci, ögretmen ve müfettiş görüşleri [Students', teachers' and inspectors' views about secondary school English coursebook Breeze 9] (Unpublished master's thesis). Retrieved from https://tez.yok.gov.tr/UlusalTezMerkezi/ (Thesis No. 308429).

Chen, S. C. (2010). Multilingualism in Taiwan. International Journal of the Sociology of Language, 205, 79-104. doi:10.1515/ijs1.2010.040

Cihan, T., and Gürlen, E. (2013). Teachers' opinions on the English language curriculum of the 5 th grade of primary education. [İlköğretim 5. sinıf İngilizce dersi öğretim programına ilişkin öğretmen görüşleri] Anadolu University Journal of Social Sciences, 13(1), 131-146. Retrieved from: http://sbd.dergi.anadolu.edu.tr/yonetim/icerik/makaleler/918-published.pdf

Council of Higher Education (2007). Türkiye'nin yüksek öğretim stratejisi. [Turkey’s higher education strategy] Retrieved from: https://www.yok.gov.tr/Documents/Yayinlar/Yayinlarimiz/Turkiyeninyuksekogretim-stratejisi.pdf

Dale, P., and Wolf, J.C. (1988). Speech communication for international students. Englewood Cliffs, NJ: PrenticeHall.

Demir-Ayaz, A., Özkardaş, S., and Özturan, T. (2019). Challenges with English language teaching in high schools in Turkey and possible suggestions to overcome them. Eurasian Journal of Applied Linguistics, 5(1), 41-55. doi: 10.32601/ejal.543778

Demirpolat, C. B. (2015). Türkiye'nin yabancı dil öğretimi ile imtihanı: Sorunlar ve çözüm önerileri [Turkey's test with foreign language education: problems and suggestions]. SETA. Retrieved from: http://file.setav.org/Files/Pdf/20150707131308_131_yabancidil_web.pdf

Demirtaş, Z., and Erdem, S. (2015). Teachers' opinions about the renewed fifth grade mathematics curriculum and opinions of teachers. [5. sinıf İngilizce dersi öğretim programı: güncellenen programın bir önceki programla karşılaştırılması ve programa ilişkin öğretmen görüşleri] Sakarya University Journal of Education, 5(2), 55-80.

Dinçer, A., and Koç, H. K. (2020). The implementation of an intensive English language program in the fifth grade in Turkey: A qualitative evaluation. [Türkiye'de yabancı dil ağırlıklı beşinci sınıf İngilizce dersi öğretim programının uygulanması: nitel bir değerlendirme] Journal of Theoretical Educational Science, 13(1), 25-43. Retrieved from: https://doi.org/10.30831/akukeg.532955 
Education First English Proficiency Index (EF EPI) (2015). The world's largest ranking of countries by English skills. Retrieved from: http://www.ef.co.uk/epi/

Er, K. O. (2006). Evaluation of English curricula in 4th and 5th grade primary schools. [ Evaluation of English curricula in 4th and 5th grade primary schools] Ankara University Journal of Faculty of Educational Sciences, 39(2), 1-25. Retrieved from : https://doi.org/10.1501/Egifak_0000000137

Erdem, S. (2016). Ortaokul-lise ögrencilerine ve Ingilizce ögretmenlerine göre Ingilizce ögretiminde karşllaşılan sorunlar [The problems encountered in English language teaching according to secondary-high school students and English language teacher] (Unpublished master's thesis). Retrieved from https://tez.yok.gov.tr/UlusalTezMerkezi/ (Thesis No. 431340).

Gülsoy, D. (2011). Ingilizce okutmanlarının ve hazırlık sınıfi öğrencilerinin dil ögrenme stratejilerinin kullanımına ve ögretimine ilişkin görüşleri [Opinions of English instructors and preperatory school students on the use and instruction of language learning strategies] (Yayınlanmamış yüksek lisans tezi). Retrieved from https://tez.yok.gov.tr/UlusalTezMerkezi/ (Thesis No. 308428).

Güngör, M., and Fişne, F. (2020). İngilizce öğretme ve izleme etkinlikleri program ilkeleri ile uyum göstermekte midir? 2. sınıflarda İngilizce öğretim programının uygulanmasına dair bakış açıları. [Do efl teaching and monitoring practices match the curricular principles? Insights into the implementation of elt curriculum in the 2nd grades.] Abant Izzet Baysal University Journal of Education, 20(1), 354-374. doi: 10.17240/aibuefd.2020.20.52925-579314

Gürel, E., and Demirhan-İşcan, C. (2020). Ortaöğretim 9.sınıf İngilizce dersi öğretim programının stake'in ihtiyaca cevap verici modeli kapsamında öğretmen görüşlerine göre incelenmesi. [Reviewing the 9th grade English curriculum with stake's responsive evaluation model according to teachers' opinions.] Çukurova University Faculty of Educational Journal, 49(1), 501-554. doi: 10.14812/cufej.623396

Güzel-Yüce, S., and Emir, G . (2020). An evaluation of the English language teaching textbooks within the context of culture of thinking. Anadolu Journal of Educational Sciences International, 10(1), 538-628. doi: 10.18039/ajesi.682060

Karasar, N. (2005). Bilimsel araştırma yöntemi Ankara: Nobel yayınları.

Lamb, M. (2007). The impact of school on EFL learning motivation: an Indonesian case study. TESOL Quarterly, 41(4), 757-780. Retrieved from: https://doi.org/10.1002/j.1545-7249.2007.tb00102.x

MacIntyre, P. D., Noels, K. A., and Clément, R. (1997). Biases in self-ratings of second language proficiency: The role of language anxiety. Language Learning, 47(2), 265-287. Retrieved from: https://doi.org/10.1111/0023-8333.81997008

Masgoret, A. M., and Gardner, R. C. (2003). Attitudes, motivation, and second language Learning: A meta-analysis of studies conducted by Gardner and 
associates. Language Learning, 53(1), 167-210. Retrieved from: https://doi.org/10.1111/1467-9922.00227

McMillan, J. H. (2012). Educational research: Fundamentals for the consumer. Boston: Pearson.

Miles, M. B., and Huberman, A. M. (1994). An expanded sourcebook qualitative data analysis. London: SAGE Publications.

O’Neill, R. (1982). Why use textbooks? ELT Journal. 36 (2), 104-111 Retrieved from: https://doi.org/10.1093/elt/36.2.104

Özbay, A., and Kayaoğlu, M. (2015). EFL teacher's reflections towards the use of computerized corpora as a teaching tool in their classrooms. [İngilizceyi yabanc1 dil olarak ögreten ögretmenlerin dil sınıflarında bir ders aracı olarak bilgisayarlı derlem kullanımına yönelik düşünceleri]. Çukurova University Faculty of Education Journal. 44(1), 85-104 doi: 10.14812/cufej.2015.005

Öztürk, G., and Aydın, B. (2019). English language teacher education in Turkey: why do we fail and what policy reforms are needed? AJESI - Anadolu Journal of Educational Sciences International, 9(1), 181-213. doi:10.18039/ajesi.520842

Paaki, H. (2013). Difficulties in speaking English and perceptions of accents a comparative study of Finnish and Japanese adult learners of English (Unpublished master's thesis). University of Eastern Finland, School of Humanities, Finland. Retrieved from: https://erepo.uef.fi/handle/123456789/13022.

Patton, M. (1990). Qualitative evaluation and research methods. Beverly Hills, CA: Sage.

Rubin, J. (1975). What the 'good language learner' can teach us, TESOL Quarterly, 9 (1) 41-51. Retrieved from: http://www.jstor.org/stable/3586011

Senemoğlu, N. (1987). Bilişsel giriş davranışlart ve dönüt-düzeltmenin erişiye etkisi [The effects of cognitive entry behavior and feedback-correction on the level of learning] (Unpublished doctoral thesis). Hacettepe Üniversitesi, Eğitim Bilimleri Enstitüsü, Ankara.

Sevinç, K. Ü. (2006). lköğretim okullarında Ingilizce öğretiminde karşılaşılan güçlüklere ilişkin öğretmen görüşlerinin değerlendirilmesi (Diyarbakır örne ği) [The analysis of teachers' views regarding the difficulties in teaching of English as a foreign language in Turkish primary schools] (Unpublished doctoral thesis). Retrieved from https://tez.yok.gov.tr/UlusalTezMerkezi/ (Thesis No. 204343).

Soğuksu, A. F. (2013). Ortaöğretim İngilizce dersi öğretim programındaki iletişimsel yaklaşımın sınıf içi uygulamalara yansıması [Reflection of the communicative approach adopted in the secondary curriculum for English in the classroom] 
(Unpublished doctoral thesis). Retrieved from https://tez.yok.gov.tr/UlusalTezMerkezi/ (Tez No. 342478).

Stronge, J. H. (2002). Qualities of effective teachers. Alexandria VA: Association for Supervision and Curriculum Development.

Student Selection and Placement Center [Ölçme, Seçme ve Yerleştirme Merkezi] (2017). Undergraduate placement exam results (Lisans yerleştirme sınavları sonuçları). Retrieved from: https://dokuman.osym.gov.tr/pdfdokuman/2017/osys/LYS/SayisalBilgiler1107 2017.pdf

The Economic Policy Research Foundation of Turkey and British Council (2013). Turkey national needs assessment of state school English language teaching. Retrieved from: https://www.britishcouncil.org.tr/sites/default/files/turkey_national_needs_asse ssment_of_state_school_english_language_teaching.pdf

Tuan, N. H. and Mai, T. N. (2015). Factors affecting students' speaking performance at le Thanh Hien high school. Asian Journal of Educational Research. 3(2), 823. Retrieved from: http://www.multidisciplinaryjournals.com/wpcontent/uploads/2015/03/FACTO RS-AFFECTING-STUDENTS\%E2\%80\%99-SPEAKING.pdf

Ur, P. (1984). Teaching listening comprehension. Cambridge: Cambridge University Press.

Weinstein, E. C., and Mayer, R. (1986). The teaching of learning strategies. (Wittock, M.C. Eds) Handbook of research on teaching, New York, NY: Maccmillan Company.

Yelgeç, N., and Dağyar, M . (2020). A structural equation modelling of middle school students' metacognitive awareness, self-efficacy beliefs and foreign language learning anxiety. International Journal of Contemporary Educational Research, 7(1) , 127-148. doi: 10.33200/ijcer.657172

Yolcu, E., and Dimici K. (2020). An analysis of foreign language oriented fifth grade english curriculum: opinions of students, teachers and administrators. Participatory Educational Research (PER), 8(1), 48-69. doi: 10.17275/per.21.3.8.1 


\section{Appendices}

Appendix-A

Descriptive analysis of language learning difficulties scale according to secondary school $7^{\text {th }}$ grade students' views

\begin{tabular}{|c|c|c|c|c|c|c|c|c|c|c|c|}
\hline \multirow{2}{*}{$\begin{array}{l}\text { Factors that } \\
\text { make language } \\
\text { learning difficult } \\
\text { Items } \\
\end{array}$} & \multicolumn{2}{|c|}{ Disagree } & \multicolumn{2}{|c|}{$\begin{array}{l}\text { Slightly } \\
\text { agree }\end{array}$} & \multicolumn{2}{|c|}{$\begin{array}{c}\text { Agree } \\
\text { moderately }\end{array}$} & \multicolumn{2}{|c|}{ Agree } & \multicolumn{2}{|c|}{$\begin{array}{l}\text { Strongly } \\
\text { agree }\end{array}$} & \multirow[t]{2}{*}{$\bar{X}$} \\
\hline & $\mathrm{f}$ & $\%$ & $\mathrm{f}$ & $\%$ & $\mathrm{f}$ & $\%$ & $\mathrm{f}$ & $\%$ & $\mathrm{f}$ & $\%$ & \\
\hline 1 & 79 & 8.4 & 186 & 19.7 & 295 & 31.3 & 213 & 22.6 & 171 & 18.1 & 3.42 \\
\hline 2 & 210 & 22.2 & 195 & 20.7 & 181 & 19.2 & 198 & 21.0 & 159 & 16.8 & 3.43 \\
\hline 3 & 269 & 28.5 & 184 & 19.5 & 157 & 16.6 & 142 & 15.0 & 191 & 20.2 & 3.79 \\
\hline 14 & 297 & 31.5 & 181 & 19.2 & 121 & 12.8 & 149 & 15.8 & 196 & 20.8 & 3.75 \\
\hline 15 & 243 & 25.7 & 141 & 14.9 & 136 & 14.4 & 190 & 20.1 & 234 & 24.8 & 4.03 \\
\hline 5 & 310 & 32.8 & 131 & 13.9 & 174 & 18.4 & 180 & 19.1 & 149 & 15.8 & 3.71 \\
\hline 7 & 381 & 40.4 & 196 & 20.8 & 135 & 14.3 & 93 & 9.9 & 138 & 14.6 & 3.37 \\
\hline 8 & 363 & 38.5 & 149 & 15.8 & 138 & 14.6 & 109 & 11.5 & 184 & 19.5 & 3.57 \\
\hline 9 & 258 & 27.3 & 180 & 19.1 & 179 & 19.0 & 137 & 14.5 & 190 & 20.1 & 3.81 \\
\hline 12 & 209 & 22.1 & 153 & 16.2 & 180 & 19.1 & 184 & 19.5 & 218 & 23.1 & 4.05 \\
\hline 13 & 52 & 5.5 & 141 & 14.9 & 187 & 19.8 & 349 & 37.0 & 215 & 22.8 & 4.56 \\
\hline 17 & 393 & 41.6 & 176 & 18.6 & 119 & 12.6 & 130 & 13.8 & 126 & 13.3 & 3.38 \\
\hline 19 & 369 & 39.1 & 156 & 16.5 & 137 & 14.5 & 122 & 12.9 & 160 & 16.9 & 3.52 \\
\hline 22 & 312 & 33.1 & 176 & 18.6 & 159 & 16.8 & 123 & 13.0 & 173 & 18.3 & 3.64 \\
\hline 26 & 338 & 35.8 & 158 & 16.7 & 166 & 17.6 & 110 & 11.7 & 172 & 18.2 & 3.59 \\
\hline 27 & 126 & 13.3 & 173 & 18.3 & 146 & 15.5 & 353 & 37.4 & 145 & 15.4 & 4.23 \\
\hline 34 & 538 & 57.0 & 138 & 14.6 & 109 & 11.5 & 76 & 8.1 & 83 & 8.8 & 2.97 \\
\hline 4 & 271 & 28.7 & 193 & 20.4 & 159 & 16.8 & 148 & 15.7 & 173 & 18.3 & 3.74 \\
\hline 10 & 307 & 32.5 & 186 & 19.7 & 155 & 16.4 & 140 & 14.8 & 156 & 16.5 & 3.63 \\
\hline 11 & 239 & 25.3 & 184 & 19.5 & 144 & 15.3 & 164 & 17.4 & 213 & 22.6 & 3.92 \\
\hline 18. & 36 & 3.8 & 32 & 3.4 & 182 & 19.3 & 415 & 44.0 & 279 & 29.6 & 4.92 \\
\hline 20 & 249 & 26.4 & 162 & 17.2 & 187 & 19.8 & 163 & 17.3 & 182 & 19.3 & 3.85 \\
\hline 21 & 296 & 31.4 & 195 & 20.7 & 174 & 18.4 & 125 & 13.2 & 154 & 16.3 & 3.62 \\
\hline 24 & 251 & 26.6 & 205 & 21.7 & 157 & 16.6 & 157 & 16.6 & 197 & 18.4 & 3.78 \\
\hline 25 & 403 & 42.7 & 48 & 5.1 & 129 & 13.7 & 237 & 25.1 & 127 & 13.5 & 3.61 \\
\hline 28 & 352 & 37.3 & 121 & 12.8 & 122 & 12.9 & 97 & 10.3 & 252 & 26.7 & 3.76 \\
\hline 29 & 306 & 32.4 & 185 & 19.6 & 148 & 15.7 & 135 & 14.3 & 169 & 17.9 & 3.65 \\
\hline 30 & 362 & 38.3 & 197 & 20.9 & 123 & 13.0 & 101 & 10.7 & 161 & 17.1 & 3.47 \\
\hline 31 & 333 & 35.3 & 178 & 18.9 & 150 & 15.9 & 137 & 14.5 & 145 & 15.4 & 3.55 \\
\hline 32 & 384 & 40.7 & 189 & 20.0 & 129 & 13.7 & 113 & 12.0 & 129 & 13.7 & 3.37 \\
\hline 33 & 511 & 54.1 & 152 & 16.1 & 95 & 10.1 & 87 & 9.2 & 99 & 10.5 & 3.05 \\
\hline 35 & 453 & 48.1 & 114 & 12.1 & 111 & 11.8 & 87 & 9.2 & 179 & 19.0 & 3.39 \\
\hline 40 & 524 & 57.5 & 118 & 12.5 & 99 & 10.5 & 76 & 8.1 & 125 & 13.2 & 3.10 \\
\hline 6. & 357 & 37.8 & 171 & 18.1 & 171 & 18.1 & 110 & 11.7 & 162 & 17.2 & 3.52 \\
\hline 16. & 36 & 3.8 & 32 & 3.4 & 182 & 19.3 & 415 & 44.0 & 279 & 29.6 & 4.92 \\
\hline 23. & 309 & 32.7 & 167 & 17.7 & 125 & 13.2 & 158 & 16.7 & 183 & 19.4 & 3.72 \\
\hline 36. & 63 & 6.7 & 142 & 15.0 & 125 & 13.2 & 297 & 31.5 & 316 & 33.5 & 4.70 \\
\hline 37. & 429 & 45.4 & 145 & 15.4 & 107 & 11.3 & 88 & 9.3 & 175 & 18.5 & 3.40 \\
\hline 38 & 333 & 35.3 & 147 & 15.6 & 142 & 15.0 & 105 & 11.1 & 217 & 23.0 & 3.70 \\
\hline 39. & 397 & 42.1 & 144 & 15.3 & 130 & 13.8 & 96 & 10.2 & 177 & 18.8 & 2.78 \\
\hline Total & & & & & & & & & & & 3.59 \\
\hline
\end{tabular}




\section{Appendix-B}

Descriptive analysis of language learning difficulties scale according to secondary school $11^{\text {th }}$ grade students' views

\begin{tabular}{|c|c|c|c|c|c|c|c|c|c|c|c|}
\hline \multirow{2}{*}{$\begin{array}{l}\text { Factors that make } \\
\text { language learning } \\
\text { difficult } \\
\text { Items }\end{array}$} & \multicolumn{2}{|c|}{ Disagree } & \multicolumn{2}{|c|}{$\begin{array}{l}\text { Slightly } \\
\text { agree }\end{array}$} & \multicolumn{2}{|c|}{$\begin{array}{c}\text { Agree } \\
\text { moderately }\end{array}$} & \multicolumn{2}{|c|}{ Agree } & \multicolumn{2}{|c|}{$\begin{array}{l}\text { Strongly } \\
\text { agree }\end{array}$} & \multirow[t]{2}{*}{$\bar{X}$} \\
\hline & $\mathrm{f}$ & $\%$ & $\mathrm{f}$ & $\%$ & $\mathrm{f}$ & $\%$ & $\mathrm{f}$ & $\%$ & $\mathrm{f}$ & $\%$ & \\
\hline 1 & 218 & 15.9 & 207 & 15.1 & 231 & 16.8 & 302 & 22.0 & 416 & 30.3 & 4.20 \\
\hline 2 & 191 & 13.9 & 195 & 14.2 & 251 & 18.3 & 307 & 22.3 & 426 & 31.0 & 4.42 \\
\hline 3 & 317 & 23.1 & 214 & 15.6 & 239 & 17.4 & 267 & 19.4 & 336 & 24.5 & 4.06 \\
\hline 14 & 65 & 4.7 & 193 & 14.0 & 228 & 16.6 & 345 & 25.1 & 543 & 39.5 & 4.80 \\
\hline 15 & 132 & 9.6 & 96 & 7 & 178 & 13.0 & 279 & 20.3 & 689 & 50 & 4.94 \\
\hline 5 & 210 & 15.3 & 179 & 13.0 & 173 & 12.6 & 514 & 37.4 & 298 & 21.7 & 4.37 \\
\hline 7 & 67 & 4.9 & 195 & 14.2 & 203 & 14.8 & 360 & 26.2 & 549 & 40 & 4.82 \\
\hline 8 & 81 & 5.9 & 205 & 14.9 & 212 & 15.4 & 239 & 17.4 & 637 & 46.4 & 4.83 \\
\hline 9 & 306 & 22.5 & 220 & 16.0 & 274 & 19.9 & 266 & 19.4 & 307 & 22.3 & 3.03 \\
\hline 12 & 293 & 21.3 & 229 & 16.7 & 202 & 14.7 & 369 & 26.9 & 281 & 20.5 & 3.08 \\
\hline 13 & 334 & 24.3 & 210 & 15.3 & 240 & 17.5 & 323 & 23.5 & 267 & 19.4 & 3.98 \\
\hline 17 & 342 & 24.9 & 209 & 15.2 & 88 & 6.4 & 284 & 20.7 & 451 & 32.8 & 4.21 \\
\hline 19 & 281 & 20.5 & 186 & 13.5 & 235 & 17.1 & 271 & 19.7 & 401 & 29.2 & 4.23 \\
\hline 22 & 114 & 8.3 & 159 & 11.6 & 261 & 19 & 269 & 19.6 & 571 & 41.6 & 4.74 \\
\hline 26 & 323 & 23.5 & 209 & 15.2 & 258 & 18.8 & 238 & 17.3 & 345 & 25.1 & 4.05 \\
\hline 27 & 132 & 9.6 & 197 & 14.3 & 212 & 15.4 & 292 & 21.3 & 541 & 39.4 & 4.66 \\
\hline 34 & 284 & 20.7 & 134 & 9.8 & 181 & 13.2 & 271 & 19.7 & 504 & 36.7 & 3.40 \\
\hline 4 & 366 & 26.6 & 219 & 15.9 & 189 & 13.8 & 263 & 19.1 & 334 & 24.3 & 3.98 \\
\hline 10 & 322 & 23.4 & 262 & 19.1 & 251 & 18.3 & 226 & 16.4 & 313 & 22.8 & 3.96 \\
\hline 11 & 218 & 15.9 & 202 & 14.7 & 198 & 14.4 & 298 & 21 & 467 & 34 & 4.42 \\
\hline 18. & 217 & 15.8 & 224 & 16.3 & 278 & 20.2 & 301 & 21.9 & 354 & 25.8 & 4.35 \\
\hline 20 & 277 & 20.2 & 232 & 16.9 & 226 & 18.6 & 226 & 18.6 & 283 & 27.9 & 4.14 \\
\hline 21 & 271 & 19.7 & 195 & 14.2 & 243 & 17.7 & 232 & 16.9 & 433 & 31.5 & 4.26 \\
\hline 24 & 185 & 13.5 & 72 & 5.2 & 176 & 12.8 & 405 & 29.5 & 536 & 39 & 4.75 \\
\hline 25 & 233 & 17 & 131 & 9.5 & 260 & 18.9 & 343 & 35 & 407 & 29.6 & 3.40 \\
\hline 28 & 425 & 30.9 & 159 & 11.6 & 166 & 12.1 & 342 & 24.9 & 282 & 20.5 & 3.92 \\
\hline 29 & 127 & 9.2 & 141 & 10.3 & 143 & 10.4 & 283 & 20.6 & 680 & 49.5 & 4.90 \\
\hline 30 & 63 & 4.6 & 218 & 15.9 & 237 & 17.2 & 213 & 15.5 & 643 & 46.8 & 4.84 \\
\hline 31 & 127 & 9.2 & 141 & 10.3 & 143 & 10.4 & 283 & 20.6 & 680 & 49.5 & 4.62 \\
\hline 32 & 250 & 18.2 & 181 & 13.2 & 206 & 15 & 264 & 19.2 & 473 & 24.4 & 4.38 \\
\hline 33 & 230 & 16.7 & 114 & 8.3 & 193 & 14 & 477 & 34.7 & 360 & 26.2 & 4.45 \\
\hline 35 & 608 & 44.3 & 167 & 12.2 & 168 & 12.2 & 154 & 11.2 & 274 & 19.9 & 3.40 \\
\hline 40 & 138 & 10 & 119 & 8.7 & 165 & 12 & 170 & 12.4 & 782 & 59.6 & 4.97 \\
\hline 6. & 393 & 28.6 & 232 & 16.9 & 191 & 13.9 & 261 & 19 & 297 & 21.6 & 2.88 \\
\hline 16. & 650 & 47.3 & 167 & 12.2 & 138 & 10 & 191 & 13.9 & 227 & 16.5 & 3.40 \\
\hline 23. & 323 & 23.5 & 216 & 15.7 & 233 & 17 & 227 & 16.5 & 373 & 27.1 & 4.28 \\
\hline 36. & 498 & 36.2 & 182 & 13.2 & 225 & 16.4 & 192 & 14 & 277 & 20.2 & 3.68 \\
\hline 37. & 615 & 44.8 & 173 & 12.6 & 184 & 13.4 & 150 & 10.9 & 249 & 18.1 & 2.64 \\
\hline 38 & 392 & 28.5 & 180 & 13.1 & 56 & 4.1 & 228 & 16.6 & 518 & 37.7 & 4.20 \\
\hline 39. & 456 & 33.2 & 206 & 15 & 209 & 15.2 & 203 & 14.8 & 299 & 21.8 & 3.76 \\
\hline Total & & & & & & & & & & & 4.18 \\
\hline
\end{tabular}




\section{Appendix-C}

\section{Semi Structured Interview Student Form}

\section{A. Demographic Information}

\section{Gender}

$\mathrm{F}(\mathrm{)} \quad \mathrm{M}(\mathrm{)}$

2. Educational Level

Secondary School ( ) High School ( )

\section{B. Foreign Language Learning Difficulties}

\section{Difficulties on Learning Materials}

1- Do you have any difficulties on the learning materials of English language lessons? If yes, what are these? Why do you regard them as difficulties?

2- What is your opinion on English text books? Are there any problems about text books? If yes, what kind of problems do you face? (Are they suitable for your needs and interests? Also think about the content, integration of the four skills, the nature of tasks, variety of activities and visuals)

\section{Difficulties related to teaching and learning process}

1- Do you have any difficulties while learning English in the classroom? If yes, what kinds of problems are there related to your learning process? (What kind of activities do you like most or what kind of tasks do you have difficulty? Which skill is the most difficult for you to learn? Why? )

2- Are there any problems related to you while learning English? If yes, what kind of difficulties do you have related to you and your study habits? (time management, motivation, self-confidence..etc.) Do you like learning English? Why? 


\section{Difficulties related to learning environment}

1 - Are there any challenges in your classrooms that make your learning process difficult? If yes, what kind of challenges do you face? (number of students, discipline problems, limited learning environment, student and teachers attitudes,...etc.) 


\section{Türkiye'de Yabancı Dil Olarak İngilizce Öğrenen Öğrencilere Göre Dil Öğrenmeyi Zorlaştıran Etkenler ${ }^{1}$}

\begin{tabular}{|c|c|c|c|}
\hline $\begin{array}{l}\text { MAKALE TÜRÜ } \\
\text { Araştırma Makalesi }\end{array}$ & $\begin{array}{c}\text { Başvuru Tarihi } \\
26.05 .2020 \\
\end{array}$ & $\begin{array}{c}\text { Kabul Tarihi } \\
12.11 .2020 \\
\end{array}$ & $\begin{array}{c}\text { Yayım Tarihi } \\
12.02 .2021 \\
\end{array}$ \\
\hline \multicolumn{4}{|c|}{ Demet Özmat (iD 2} \\
\hline \multicolumn{4}{|c|}{ Çankaya Üniversitesi } \\
\hline \multicolumn{3}{|c|}{ Nuray Senemoğlu (iD 3} & \\
\hline
\end{tabular}

Öz

$\mathrm{Bu}$ araştırmada İngilizce öğrenme sürecinde yaşanan zorlukların öğrenciler tarafindan belirlenmesi hedeflenmiştir. Türkiye' de dil ögrenme ve öğretme sürecinde yaşanan zorlukların belirlenmesi, bu zorlukların giderilmesi bakımından önemlidir. Bu araştırmanın çalışma grubunu Ankara ilindeki Milli Eğitim Bakanlığına bağlı Anadolu liselerinin 11. sınıf ve devlet ortaokullarının 7. sınıf öğrencileri oluşturmaktadır. Çalışmaya toplam 2,317 öğrenci katılmıştır. Çalışmanın veri toplama araçları, araştırmacılar tarafından geliştirilen Dil Öğrenmeyi Zorlaştıran Faktörler (DÖZF) Ölçeği (2017) ve yarı yapılandırılmış görüşme formudur. Verilerin çözümlenmesinde SPSS paket programı MaxQda 12 programından faydalanımıştır. Çalışmanın bulguları hem 7. hem de 11. sınıf öğrencilerin dil öğrenme sürecinde yüksek düzeyde zorluk yaşadığını göstermiştir. Buna ek olarak, 7. Sınıf öğrencilerinin İngilizce öğrenirken yaşadığı zorluklar, lise 11. sınıf öğrencilerinin yaşadığı zorluklara göre daha az düzeydedir. Çalışmanın nitel sonuçlarına göre, öğrencilerin ortak olarak en sık yaşadıkları zorluklar; ders kitaplarının yetersiz oluşu, İngilizce ders kitaplarının öğrencilerin günlük yaşamlarında kullanacakları metinleri içermemesi, derslerde konuşma ve dinleme becerilerinin gelişimine ilişkin etkinlik yetersizlikleri, derslerde dil öğrenme stratejilerine yer verilmemesi, İngilizceye karşı özgüven eksikliği, kalabalık sınıflar ve disiplin sorunlarıdır.

Anahtar sözcükler: Yabancı dil öğrenme, program geliştirme ve öğretim, betimsel araştırma, ölçek geliştirme çalışması, yabancı dil öğrenmeyi zorlaştıran etkenler.

Etik Kurul Raporu: Bu araştırma, Hacettepe Üniversitesi etik kurul onayı (No: 35853172/4331058, Tarih: 08.04.2016) ve Ankara İl Milli Eğitim Müdürlügünün izni (No: 14588481-605.99E.5149315,Tarih: 09.05.2016) ile yapılmıştır.

${ }^{1}$ Bu çalışma, Hacettepe Üniversitesi, Eğitim Programları ve Öğretim bilim dalında, Aralık 2017 yılında Prof. Dr. Nuray Senemoğlu danışmanlığında yürütülen doktora tez çalışmasından üretilmiştir.

${ }^{2}$ Sorumlu Yazar: Dr., Yabancı Diiler Bölümü, e-posta:demetgulsoy@cankaya.edu.tr, https://orcid.org/0000-0002-8936-020X

${ }^{3}$ Prof. Dr., Eğitim Fakültesi, Eğitim Bilimleri, Eğitim Programları ve Öğretim Anabilim Dalı, e-posta: n.senem@ hacettepe.edu.tr, https://orcid.org/0000-0001-9657-0339 
Yabancı dil bilmenin ve yabancı dilde iletişim kurabilmenin bilim ve teknolojiye ayak uydurabilmek için gerekli donanımlar arasında olduğu bilinen bir gerçektir. Yabancı dil öğrenimine yönelik yapılan birçok program değerlendirme çalışmaları da yabancı dil öğretme ve öğrenmede zorluk yaşandığını göstermektedir (Ağçam ve Babanoğlu, 2018; Demir-Ayaz, Özkardaş ve Özturan, 2019; Demirpolat, 2015; Erdem, 2016; Gürel ve Demirhan-İşcan (2020). Bunlara ek olarak, ülkemizin İngilizce dil yeterliğine yönelik çalışma sonuçlarının da çok iç açıcı olduğu söylenemez (English Proficiency Index [İngilizce Yeterlik Endeksi], 2015). Dolayısı ile yapılan İngilizce program değerlendirme çalışmaları, yabancı dilde yaşanan zorlukları belirlemeye yönelik benzer çalışmalar ve ülkemizde İngilizce düzeylerinin sonuçlarını derleyen çalışmaların sonuçları doğrultusunda, bu çalışmada da dil öğrenmede yaşanan zorluklar öğrenciler gözünden belirlenmeye çalışılmıştır.

\section{Amaç ve Önem}

$\mathrm{Bu}$ araştırmada amaç, ortaokul ve lise öğrencilerin dil öğrenme geçmişleri boyunca karşılaştıkları zorluklara yönelik görüşlerini belirlemek ve zorlukların giderilmesinde çözüm çabalarına katkı sağlamaktır. Araştırma 2,317 öğrenci ile yürütülmüş̧ür ve bu bakımdan oldukça kapsamlı bir çalışma olduğu düşünülmektedir. Çalışma aynı zamanda bir ölçek geliştirme çalışmasını da içerdiği için benzer konuda yapılacak yeni çalışmalarda kullanılabilir olması bakımından da önemli görülmektedir. Bunlara ek olarak; bu araştırma, ülkemizde İngilizce öğrenmede yaşanan başarısızlık nedenlerini öğrenciler gözünden incelemeye yönelik olup, araştırmada yabanc1 dil öğrenen öğrencilere, öğretmenlere, yabanc1 dil programı geliştiricilere, yabancı dil eğitimi konusunda yapılan ve yapılacak çalışmalara katkı sağlamak amaçlanmıştır. Edinilen bilgilerin, ülkemizde dil öğretme ve öğrenme sürecinde yaşanan zorlukların belirlenmesi ile bu zorlaştıran değişkenlerin giderilmesine 1 şık tutacağı düşünülmektedir. Bu kapsamda, araştırmada aşağıdaki sorulara yanıt aranmıştır:

1. Ortaokul 7. ve lise 11. sinıf öğrencileri dil öğrenme sürecinde ne düzeyde zorluk yaşamaktadır?

2. Öğrencilerin İngilizce öğrenmeyi zorlaştıran etkenlere ilişkin görüşleri sınıf düzeylerine göre farkl11ık göstermekte midir?

3. Ortaokul 7 ve lise 11. sınıf öğrencileri ile yapılan görüşme sonuçlarına göre İngilizce öğrenmeyi zorlaştıran etkenler nelerdir?

\section{Yöntem}

$\mathrm{Bu}$ araştırmada ortaokul 7. ve lise 11. sınıf öğrencilerine göre İngilizce öğrenmeyi zorlaştıran etkenlerin betimsel yöntemle belirlenmesi için veriler nicel ve nitel yollarla elde edilmiştir. Bu araştırma, Hacettepe Üniversitesi etik kurul onayı (No: 35853172/ 433-1058, Tarih: 08.04.2016) ve Ankara İl Milli Eğitim Müdürlüğünün izni (No: 14588481-605.99-E.5149315,Tarih: 09.05.2016) ile yapılmıştır. 
Çalışma Grubu. Çalışma grubunu 2015-2016 öğretim yılında Ankara ilindeki Milli Eğitim Bakanlığı'na bağlı devlet ortaokullarının 7. ve Anadolu liselerinin 11. sınıf öğrencileri oluşturmaktadır. Araştırma kapsamına alınmış olan okullar, orantılı tabakalı amaçlı örnekleme yöntemine göre alt orta ve üst başarı grubuna ayrılmıştır. Çalışmaya Ankara ili merkez ilçelerindeki okullardan düşük, orta ve yüksek başarı düzeyinde öğrenim gören ortaokul 7. sınıf düzeyinden 944 öğrenci ve Anadolu liselerinden düşük, orta ve yüksek başarı düzeylerindeki okullarda öğrenim gören lise 11. sınıf düzeyinden 1,373 öğrenci olmak üzere toplam 2,317 öğrenci katılmıştır. Araştırmanın nitel verilerini toplamak için toplam 70 öğrenci ile yüz yüze görüşme yapılmıştır (40 ortaokul 7. sınıf öğrencisi ve 30 lise 11. sınıf öğrencisi).

Veri Toplama Araçları ve Geliştirilmesi. Araştırma verilerini toplamak üzere araştırmacılarca geliştirilen, öğrenciler için Dil (İngilizce) Öğrenmeyi Zorlaştıran Faktörler (DÖZF) Ölçeği ve öğrencilerin görüşlerini almak üzere hazırlanan yarı yapılandırılmış görüşme formları kullanılmıştır.

Ölçek geliştirme sürecinde, pilot uygulama seçkisiz örnekleme yöntemi ile belirlenen 437 öğrenciye uygulanmıştır. Hem lise hem de ortaokul öğrenci grubundan elde edilen verilere ayrı ayrı açımlayıcı faktör analizi uygulanmıştır. Ortaokul öğrencilerine uygulanan nihai ölçeğin güvenirlik değeri .93, lise öğrencilerine uygulanan nihai ölçeğin güvenirlik değeri ise .92 olarak hesaplanmıştır.

Araştırmanın nitel boyutu için geliştirilen yarı yapılandırılmış görüşmeler katılımcıların onayı alınarak ses kayıt cihazı ile kaydedilmiştir. Transkriptler, MaxQda 12 programı kullanılarak tümevarımsal içerik analizi yöntemi ile analiz edilmiştir. Güvenirliğin hesaplanmasında, Miles ve Huberman'ın (1994) önerdiği uyuşum yüzdesi formülü kullanılmıştır. Verilerin uyum yüzdesi .81 olarak hesaplanmıştır.

Verilerin Analizi. DÖZF ölçeğinden elde edilen verilerin analizinde ortalama, yüzde, sıklık hesaplanmıştır. Ortaokul-lise öğrencilerinin görüşlerinin karşılaştırılmasında bağımsız gruplar için t-testi kullanılmıştır. Nitel verilerin analizi için MaxQda 12 nitel veri analiz yazılım programı ile tema ve kodlar belirlenmiştir. Belirlenen kodlar ve temalar üzerinden sıklık ve yüzde değerleri belirlenmiştir.

\section{Bulgular}

DÖZF ölçeğine ait toplam aritmetik ortalama değerlerinin hem 7.sınıf $(\bar{X}=3.59)$ hem de 11. sınıf $(\bar{X}=4.18)$ öğrencileri için yüksek olduğu görülmektedir. Ölçekte kapsanan zorlukları her iki grubun da yüksek derece yaşadıkları görülmektedir. Ortaokul 7. sınıf öğrencileri sırasılya, öğretimin niteliği (öğretme-öğrenme ortamı), öğrenme iklimi, öğrenme kaynakları ve öğrencilerin kendilerinden kaynaklanan zorlukları cok yüksek düzeyde yaşamaktadır. Lise 11. sınıf öğrencileri ise sırasıyla, öğrenme kaynakları, öğrencilerin kendilerinden kaynaklanan zorluklar, öğretimin niteliği ve öğrenme ikliminden kaynaklanan zorlukları çok yüksek düzeyde yaşamaktadır. 
7. sınıf öğrencileri ile 11. sınıf öğrencilerin karşılaştıkları zorluklara ilişkin görüşleri arasında anlamlı bir fark olup olmadığını belirlemek için bağımsız gruplar için $\mathrm{t}$ testi yapılmıştır. 7. sınıf öğrencilerinin yaşadıkları zorluklara ilişkin elde edilen aritmetik ortalama $(\bar{X}=143.67)$ ile 11. sınıf öğrencilerinin yaşadıkları zorluklara ilişkin aritmetik ortalama ( $\bar{X}=167.37)$ arasında anlamlı fark bulunmaktadır $[\mathrm{t}(2317)=$ 19.216, p<.05]. Diğer bir ifade ile 7. Sınıf öğrencilerinin yaşadıkları zorluk düzeylerinin lise 11. sınıf öğrencilerinin yaşadıkları zorluk düzeyine göre daha az olduğu belirlenmiştir.

Çalışmanın nitel boyutunu oluşturan görüşme formlarından elde edilen bulgulara göre, öğrenme kaynaklarından ve materyalden kaynaklanan zorluklar, öğrencilerin kendilerinden kaynaklanan zorluklar, öğretme- öğrenme ortamından (öğretimin niteliği) kaynaklanan zorluklar ve öğrenme ikliminden kaynaklanan zorluklar olmak üzere dört tema ve kodlar ortaya çıkmıştır. Her iki grubun öğrencilerinin ortak olarak en sık yaşadıkları zorluklar, İngilizce ders kitaplarının içinde, öğrencilerin iletişim becerilerini ve günlük yaşamda kullanabilecekleri metinler olmaması, derslerde görsel ve işitsel araç gereç kullanımının yetersiz olması, dil öğrenme stratejilerinin kullanımına ve öğretimine derslerde yer verilmemesi, okul dışında İngilizce öğrenmeye yeterli zaman ayıramama ve öğretme-öğrenme ortamında yaşanan disiplin sorunları ve sınıfların kalabalık olmasıdır.

\section{Tartışma, Sonuç ve Öneriler}

$\mathrm{Bu}$ araştırmada DÖZF ölçeğinden elde edilen bulgulara göre, öğrenme kaynaklarına yönelik öğrenciler, ders kitaplarının içerisindeki metinlerin çok uzun olduğunu ve okurken çok fazla bilinmeyen sözcüklerle karşılaştıklarını, derslerde kullanılan işitsel ve görsel etkinlikleri ve teknolojinin etkili kullanımının yetersiz olduğunu dile getirmiştir. Öğrenciler sınavlarında/yazılılarda konuşma bölümü olmadığı için konuşma etkinliklerine önem vermediklerini belirtmiştir. Elde edilen bu bulgular, dil öğrenmede başarısızlık nedenlerinin araştırıldığı diğer çalışma sonuçlarının öğrenme kaynaklarına yönelik bulguları ile de paralellik göstermektedir (Aduwa-Ogiegbaen ve Iyamu 2006; Akkuş, 2009; Aslantürk, 2011; Çelik, 2011; Demir-Ayaz vd., 2019; Lamb, 2007). O’Neill (1982) dil öğretiminde ders kitaplarının dört önemli işlevinden söz etmiştir. Bunlar, kitaplar sadece öğrencilere özel olmasa da onların gereksinimlerine uygun olmalı, daha önce öğrendiklerini tekrar etmelerini ve aynı zamanda ilerlemelerine olanak sağlamalı, yeterli materyaller sunmalı ve hem öğretmenler hem de öğrenciler tarafından sınıf içinde etkileşim uygulamalarına olanak sağlamalıdır. Bu durumda bu çalışmadan elde edilen bulgular göz önünde bulundurulduğunda, alanyazında belirtilen ölçütleri kapsamadığı, öğrencilerin görüşlerine göre öğrenme kaynakları ile ilgili olarak dersin kitaplarının içerik, düzey, öğretme ve öğrenme etkinlikleri bakımından öğrencilerin gereksinimlerine yanıt veremediği ve teknolojik araçlarla yeterince desteklenmemesi nedenleriyle İngilizce öğrenmelerini zorlaştırdığı söylenebilir.

Öğrencilerin öğretimin niteliğine ilişkin görüşlerine göre, hem ortaokul hem de lise öğrencileri ortak olarak dinleme ve konuşma etkinliklerini yetersiz bulmaktadır. 
Buna ek olarak lise öğrencileri, derslerde daha fazla dinleme etkinlikleri yapılmasını önermiştir. Alanyazında konuşma ve dinleme becerilerinin gelişiminde etkili olan faktörlere bakıldığında ise öğrencilerin $\mathrm{s} 1 \mathrm{k}$ sık dinleme etkinliklerine dahil edilmesinin ve dinleme becerisini geliştirirken farklı ve dikkat çekici etkinlikle desteklemesinin önemi vurgulanmıştır (Ur, 1984). Dolayısı ile bu araştırmadan elde edilen bulgular, öğrencilerin kendilerini özellikle dinleme ve konuşma becerisinde başarısız görmeleri, derslerde bu becerilerin geliştirilmesine yeterince yer verilmediği ve nelere dikkat edecekleri konusunda yol gösterilmediği nedenlerine bağlanabilir. Bunlara ek olarak ölçekten elde edilen bulgular doğrultusunda, öğrencilerin yazma, dinleme ve sözcük öğrenme gibi becerilerin gelişiminde nasıl öğrenecekleri ve hangi yolları izleyecekleri konusunda yüksek derecede zorluk yaşadıkları görülmüştür. Öğrenci görüşmelerinden elde edilen bulgular da öğrenme stratejilerine duyulan bu zorlukları açıklar niteliktedir.

$\mathrm{Bu}$ araştırmada 7. sınıf öğrencilerinin dil öğrenme sürecinde yaşadıkları zorluklar ile 11. sınıf öğrencilerinin yaşadıkları zorlukların düzeyleri karşılaştırıldığında, 7. sınıf öğrencilerinin 11. sınıf öğrencilere göre daha az düzeyde zorluk yaşadıkları belirlenmiştir. Elde edilen bu bulgu, Türkiye Ekonomi Politikaları Araştırma Vakfı (TEPAV) ve British Council (2013) ortaklığında Türkiye çapında İngilizce'nin öğretimine ilişkin yapılan geniş odaklı çalışmanın sonuçları ile örtüşmektedir. Çalışmanın sonuçlarına göre, öğrenciler eğitim sisteminde daha üst sınıflara ilerledikçe, kendi İngilizce düzeylerini daha düşük olarak değerlendirdikleri ve sınıfları yükseldikçe güdülenme düzeylerinin azaldığı belirlenmiştir. Dolayısı ile İngilizce'nin de aşamalılık ilişkisi gösteren bir ders olduğu düşünüldüğünde, öğrencilerin 11. sınıfa gelinceye kadar eksik öğrenmelerinin bulunduğu, gerekli ön koşul öğrenmelerinin tamamlanamadığı ve daha alt sınıflarda tam öğrenmelerin sağlanamadığı için sınıf düzeyi arttıkça öğrencilerin yaşadıkları zorlukların da arttığı sonucuna varılabilir.

$\mathrm{Bu}$ araştırmadan elde edilen bulgular sonucunda, hem ortaokul hem de lise İngilizce ders kitaplarının öğrencilerin ilgi, gereksinim ve dil öğrenme becerilerinin gelişimi göz önünde bulundurularak yeniden düzenlenmesine gereksinim vardır. Okuma metinleri, öğrencilerin okuduğunu anlamasını özendirecek nitelikte olmalı, bilinen ve bilinmeyen sözcüklerin dengesi sağlanmalıdır. Aynı zamanda kitapların düzeyi de dilbilgisi bakımından güncellenmelidir.

İngilizce dersi öğretim programlarına sesletim öğretiminin eklenmesine, sınavlarda ise yabancı dilde iletişim becerilerinin ölçülmesine ihtiyaç vardır. Öğretimin düzenlenmesinde öğrencileri etkin kılacak, İngilizce konuşma ve dinleme becerilerini geliştirecek ve iletişim becerilerini kullanmalarına firsat verecek öğretme ortamları oluşturulmalıdır. İngilizce eğitim programlarında dil öğrenme ve öğretme stratejilerine yer verilmelidir. Öğretmenlere de dil öğrenme stratejilerinin öğretimine ilişkin eğitimler verilmelidir.

Öğrencilerin sınıf düzeyi arttıkça yaşadıkları zorluk düzeylerinin arttığı sonucu göz önünde bulundurulduğunda, her sınıfta istendik davranışların kazandırılması için 
gerekli ön koşul öğrenmelerin neler olduğu tanımlanmalı, bir üst sınıfa geçildiğinde de eksikler tamamlanarak başlanmalıdır. Bu anlamda, bu amacı taşıyan program geliştirme çalışmalarına ağırlık verilmelidir.

Bu araştırma Ankara ilindeki 2,317 ortaokul ve lise öğrencisinin görüşleri ile sınırlıdır. Yeni yapılacak olan araştırmalara dönük olarak dil öğrenme stratejilerinin öğretme-öğrenme ortamında kullanımına ve öğretimine ilişkin hem öğretmenlere hem de öğrencilere yönelik deneysel çalışmalar yapılabilir. Farklı öğrenim düzeylerinde dil öğretme ve öğrenmeye yönelik aynı araştırma yapılabilir ve sonuçları karşılaştırılabilir.

\section{Etik Kurul Raporu}

Bu araştırma, Hacettepe Üniversitesi etik kurul onayı (No: 35853172/ 433-1058, Tarih: 08.04.2016) ve Ankara İl Milli Eğitim Müdürlüğ̈̈nün izni (No: 14588481605.99-E.5149315,Tarih: 09.05.2016) ile yapılmıştır. 